* Corresponding autho

Phone +421556022520

E-mail address:milan.oravec@tuke.sk

(prof. Ing. Milan Oravec, PhD)

Article information

Article history: AMS-Volume16-No.1-00145-12

Received 4 January 2012

Accepted 15 March 2012

\section{Risk Assessment Tools for Nonlinear Dynamic Systems}

\author{
Milan Oravec*, Barbora Kováčová \\ Technical university of Košice, Faculty of Mechanical Engineering, Institute of Safety, Quality and Environmental Science, Department of \\ Safety and Production Quality, Letná 9, 04200 Košice
}

\section{BIOGRAPHICAL NOTES}

Milan Oravec, prof. Ing. PhD. works at the Department of Safety and Quality of Production, Faculty of Mechanical Engineering, Technical University of Košice. He has been conducting research into risk assessment since the establishment of this field of study at the Technical University of Košice (1990). He defended his PhD thesis on Mutual Interaction of Design Spectrum of a Traversing Crane in 1992 in the field of Oscillation. He habilitated in 1995 in the field of Quality of Production and the Safety of Technical Systems, with work on Identification and Control of Technical Risks. In 2009 he was inaugurated in the field of Safety and Fire Protection at the Faculty of Safety Engineering VŠB - Technical University of Ostrava, with work on Risk Assessment - Safety of Mechanical Systems, Chemical Plants and Linear Constructions.

In recent years he has been focused on the development of methods and procedures in the field of prevention of industrial accidents, safety of road tunnels and safety of linear constructions. He is currently dealing with developing integral risk assessment methods in critical infrastructure under asymmetric threats. He cooperates with numerous prestigious institutions that develop state-of-the-art technologies in the field of safety.

Barbora Kováčová, Ing. is an internal PhD student at the Department of Safety and Quality of Production, Faculty of Mechanical Engineering, Technical University of Košice. She received her Master level degree in 2009 in the field of Process Control in Extracting and Processing of Raw Materials at the Institute of Control and Informatization of Production Processes, Faculty of Mining, Ecology, Process Control and Geotechnologies, Technical University of Košice. Her current research focuses on synergic effects in the risk management process.

\section{KEYWORDS}

Causal dependence, risk assessment, safety, synergic effect, deterministic chaos

\begin{abstract}
Tools for quantitative risk assessment used in praxis are predominantly based on linear transformations. A parallel problem of current risk assessment methods is constant time and imperceptions of variability of threat over the course of time. Bertalanffy, Wiener, Haken, and Prigogine emphasized interdisciplinary approach and its potential utilization in risk assessment. Two specific cases of causal dependence are domino effect and synergic effect. Risk as an attribute of causal dependence is common for all present management systems. The paper deals with details of synergic effect mechanism, its identification and possible utilization in the field of safety.
\end{abstract}




\section{Introduction}

Risk assessment is a basic tool of every management system. It enables appropriate decision making. Implementation of technology in our living environment constantly brings about new threats. Being prepared to manage risks involves the ability to identify them, assess them and take appropriate measures. The developments in science and technology help save labour and increase productivity. Systematic approach enables today's technicians to perceive mutual interactions of respective parts of mechanic systems and technological units. Today's construction does not only involve the manufacture of products but also designing procedures for other areas of human activity. There arise numerous interdisciplinary methods that enable us to create new products. However, new products bring about new threats. The necessity of minimizing such threats is a highly topical requirement.

Safety of technical and technological systems (chemical, petrochemical and gas) began to be taken more seriously in the 1960's, because of technological accidents with consequences lasting over decades. As a result, directive SEVESO II and related activities concerning technological systems have been implemented.

Safety of linear systems (transport and distribution of gas, oil, electricity and materials via road and railroad transport) is just a logical outcome of perceiving safety more comprehensively. The safety issues of critical infrastructure reflect current threats, which are not only of technological nature. The mankind needs to deal with modern threats (natural, technological, socioeconomic, and asymmetric).

\section{Development of tools supporting decision making in management systems}

Scientific principles were first applied in the theory of accidents by H.W. Heinrich [1], author of the domino theory of accident causation. The domino model theory was disproved by W. Shewhart. Shewhart's results served as a basis for F. Bird's Loss causation model. The process approach by W. E. Deming and J. M. Juran in the 1950's pointed out the role of a human being. Human behaviour is critical in the management process. The process approach brought a new view of risks and risk management.

The level of comprehensive safety certainly de- pends on the degree of integration of its partial components. The issues of integration are related to the subject of enterprise, policy, and personalities of managers, able to use their knowledge to manage the subsystems in an integrated way.

Ludwig von Bertalanffy [2], the founder of the general systems theory applicable to biology and other fields, proposed the equifinality principle (the same end state may be achieved via many different paths or trajectories within a system). Wiener's work $[3,4]$ contributed to the systematic perception of technical systems. In the late 1960's, he suggested interdisciplinary approach within the theory of systems. The term synergetics was presented by Haken in 1969 at the University of Stuttgart. The theoretical issues of nonlinearities near equilibrium state were elaborated by Ilja Prigogin [5].

Current technical and management systems are presented as dynamic management systems that are constantly being improved. This approach is formal and commercionalized. However, a standard or a regulation is just a summary of the existing knowledge. The interdisciplinarity of approaches requires deeper and more systematic understanding of the problem. In spite of the existence of tools such as ISO31 000, and generic management, it is not possible to claim that integration utilizing approaches formalizing such ideas for risk assessment have been created.

\section{Current knowledge and its application in the theory of risks}

Every system can be considered safe at a particular point of time if three basic axioms are met:

\section{- Stability of external environment (external rela-} tions),

- Stability of the internal environment (internal relations),

- Selection of suitable components that determine threat minimization (system components).

The term risk as an attribute of causal dependence is common for all management systems. The word is of Arabic origin, and originally it meant either favourable or unfavourable event in human life. Its meaning was later narrowed to denote only unfavourable events. In relation to the development of technological sciences and emerging problems, accidents and disasters, this term has become to be used in quantification of causal de 
pendence, not only in quantification of the result. Present economics connects the term risk with ambiguity of the course of particular circumstances, economic processes and ambiguity of their outcomes.

Current management approaches require integration of systems into one unit. Today, this process is understood as integration of structures not of entire subsystems. However, much more important task rests in the integration of systems, i.e. not mere system components but also their relations that give rise to characteristic threats.

The complexity of safety problems is not only the matter of internal issues of companies. Functionality issues of companies towards external threats are increasingly gaining importance. ISO 25 999, 27 00x, $2900 x$, and 31000 serve as an example of it. That is why planning and management of continuity of activities is gaining attention. In this context, it is important to take into consideration those companies in which it is not possible to interrupt production.

FTA $\square$ fault tree analysis

\subsection{Causal dependence}

The concept of the causal dependence is as old as humanity itself. In 1950's and 1960's, there was a significant development of numerous important scientific disciplines related to systematic approach. Synergetics as a scientific discipline deals with concurrence of respective systems within a complex system. This gives rise to complex structures, new behaviours and new qualities that are not mere sums of subsystems. Domino effect and synergic effect are specific cases of causal dependence. A qualitative change form one stage to another caused by a change in external conditions is called a sudden phase change. All phase changes are its typical examples - industrial accidents, natural disasters, as well as ordinary operation accidents such as boiling liquid expanding vapour explosion (BLEVE). In spite of the fact that we usually take notice only of the consequences of such events, their mechanisms contain a sequence of events - causal dependence. In case of synergic effect there occurs a permanent structural change.

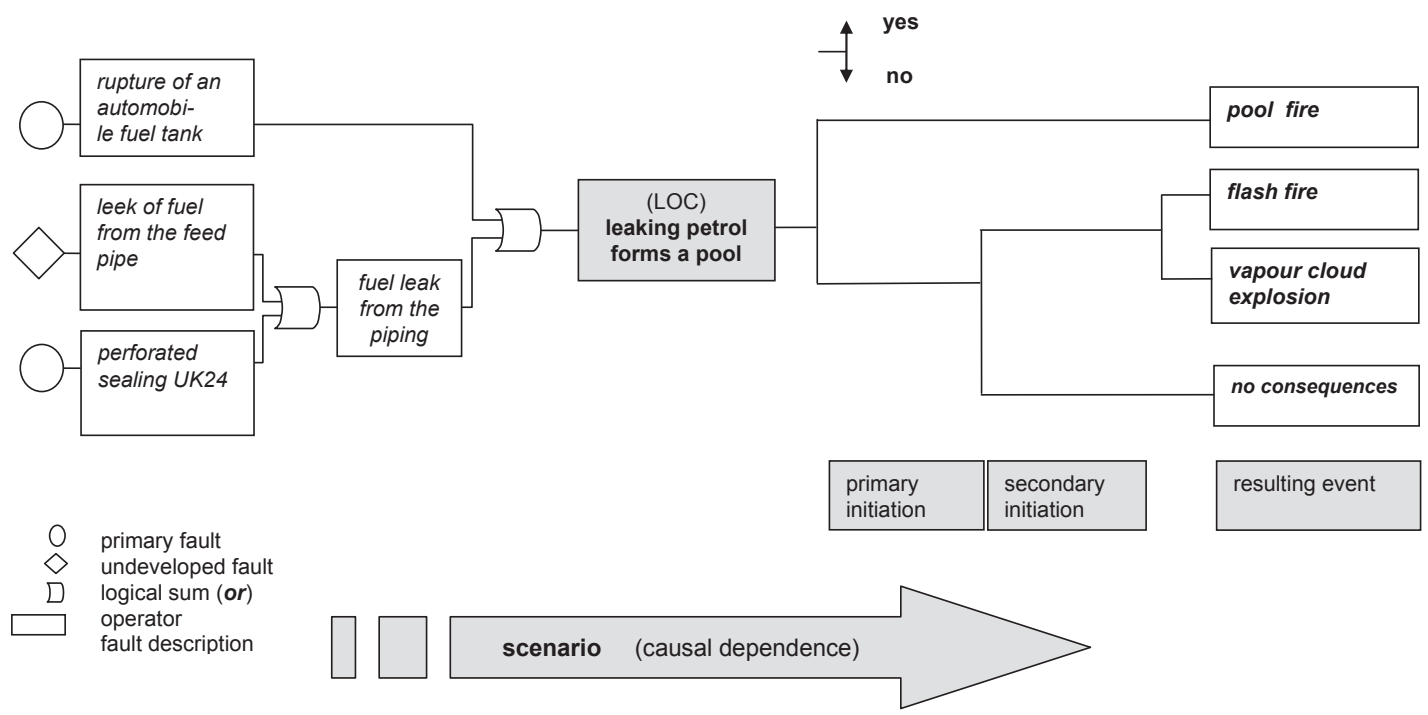

Fig. 1: Causal dependence.

All risk assessment procedures, both deductive and inductive, use causal dependence, shown in Figure 1. Quantification of risk is necessary for the economic aspect of prevention. The processes have often been simplified in search of relevant physical and chemical basis. Some details had been neglect- ed in the simplification process, which later caused catastrophes.

In the description of causal dependence it is advisable to take into consideration also consequences that are possible in particular time and space. 
3.2 Systematic view and the theory of risk - formulation

Systematic view and time dependent understanding of risks [6] allows wider application of the theory of risks. Mathematical formulation of such procedure is as follows:

If system $S$ is given by the set of elements and relations $\mathrm{j}$

$S \in\left\{s_{i, j}\right\}$

where: $i=1, n$ is a number of elements with characteristic hazards; $j=1, m$ is a number of relations with characteristic threats.

In the realization of a system's objective function, e.g. manufacture of a product, the system is activated together with its characteristic threats. On the part of the user of the system (management) there exists a set of requirements on the system

$K \in\left\{k_{i, j}\right\}$

where: $i=1, n$ is a requirement on ith element; $j=1$, $m$ is a requirement on jth relation.

The resulting risk is then formed by an existing set of phenomena, formal notation of which is:

$R=S \cap K$

Since the set $\mathrm{K}$ is the function of time and changes according to the management's requirements, new interactions and new risks arise constantly. In common praxis the number of combinations is limited by the construction and space - surroundings. It changes its form for application in praxis, so that it is easy to solve tasks concerning time-dependent risks for ith risk and understand the situation within the limits of integral risk

$R_{i}=\left(e_{i}, n_{i}, p_{i}, t_{i}\right)$

where: $e_{i}$ is a particular phenomenon, $n_{i}$ is a consequence, $\mathrm{p}_{\mathrm{i}}$ is probability in a particular time interval $t_{i}$. Current findings in the field of safety of technological and territorial units within the operation continuity plans prove that it is necessary to take into account emerging risks that predominantly affect the system from the outside.

The aim of efforts in the field of risks is minimization of loss [7]. In economics, risk is a potential of an activity to lead to a loss of assets. The equation 4 can be formulated as follows:

$R=f(z, p, t)$

where: $\mathbf{z}$ is a loss, $\mathbf{p}$ is probability (occurrence), and $\mathrm{t}$ is time.

\subsection{Economy of prevention and risk}

In prevention it is important to take measures before the threat is activated. Prevention within the causal dependence is shown in Figure 2.

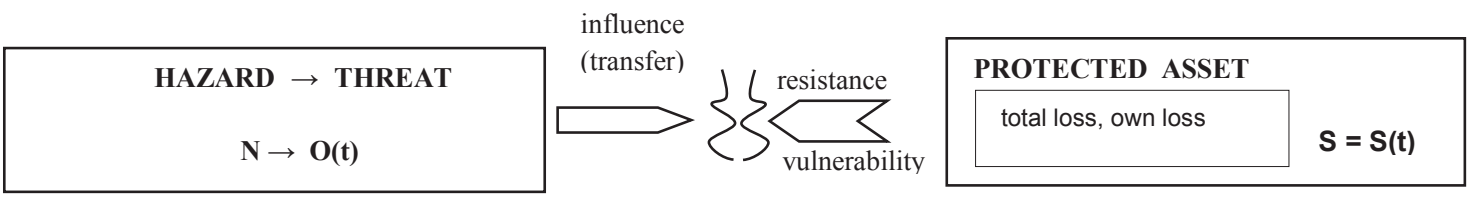

Fig. 2: Prevention solutions in causal dependence [7].

Table 1: Interaction threat / asset.

Resistance is characteristic for a particular system, which is financially expressed in the form of an asset. The resistance can be either natural or supplementary (increased on purpose) [7]. Table 1 shows a simple interaction threat / asset.

In reality, the situation is much more complex, as expressed in equation 3. During the influence of the threat on the asset, the influence is changing in consequence of the resistance of the system. If the influence of the threat on the asset is quantified in one cumulated indicator $\mathrm{Hi}$, it is possible to formulate equation 5 for a particular state as follows:

\begin{tabular}{|c|c|c|c|c|c|c|c|c|}
\hline \multicolumn{10}{|c|}{ Threats Hj (induced, secondary) } \\
\hline & & $\mathrm{H}_{1}$ & $\mathrm{H}_{2}$ & $\ldots$ & $\mathrm{H}_{\mathrm{i}}$ & $\ldots$ & $\mathrm{H}_{\mathrm{n}}$ & ? \\
\hline & $\mathrm{H}_{1}$ & $\mathrm{H}_{1}$ & $\mathrm{H}_{12}$ & & $\mathrm{H}_{1 \mathrm{i}}$ & & $\mathrm{H}_{1 \mathrm{n}}$ & \\
\hline & $\mathrm{H}_{2}$ & $\mathrm{H}_{21}$ & $\mathrm{H}_{2}$ & & $\mathrm{H}_{2 \mathrm{i}}$ & & $\mathrm{H}_{2 \mathrm{n}}$ & \\
\hline & $\ldots$ & & & & & & & \\
\hline & $\mathrm{H}_{\mathrm{i}}$ & $\mathrm{H}_{\mathrm{i} 1}$ & $\mathrm{H}_{\mathrm{i} 2}$ & & $\mathrm{H}_{\mathrm{i}}$ & & $\mathrm{H}_{\mathrm{in}}$ & \\
\hline & $\ldots$ & & & & & & & \\
\hline $\mathrm{H}_{\mathrm{n}}$ & $\mathrm{H}_{\mathrm{n} 1}$ & $\mathrm{H}_{\mathrm{n} 2}$ & & $\mathrm{H}_{\mathrm{n}}$ & & $\mathrm{H}_{\mathrm{n}}$ & \\
\hline
\end{tabular}

$H_{k \leftarrow i}=H_{i} * \eta_{i k}=R_{k-i}$ 
where: $\eta_{i \mathrm{k}}$ is a coefficient of the influence of the threat $\mathrm{i}$ on the asset $\mathrm{k} . \mathrm{R}_{\mathrm{k} \rightarrow \mathrm{i}}$ is a risk to asset $\mathrm{k}$ caused by threat i. The situation between the threat $\mathrm{Hi}$ and the asset $\mathbf{A}_{k}$ is determined in the coefficient of transfer $\eta_{\mathrm{ik}}{ }^{\top}$ and the resistance $\eta_{\mathrm{ik}}{ }^{\circ}$. The total coefficient of the influence is

$$
\eta_{i k}=\eta_{i k}{ }^{T} * \eta_{i k}{ }^{O}=R_{i k} / H_{i}
$$

\section{New risk assessment tools}

Tools for quantitative risk assessment in praxis are generally based on linear transformations. Another problem is the constant time, i.e. not taking into consideration the changing nature of threat over the course of time. Human activity remains the most serious problem. A human represents various nonlinearities simultaneously.

Mathematical models as well as currently used methods are simplifications that are frequently usable only when remaining system parameters are fixed. It will be necessary to deal with specific phe- nomena such as synergic effect and domino effect as parts of causal dependence in the field of economics, strategic management but also in general chemistry. New procedures able to identify serious non-equilibrium states of systems with the potential of sudden changes are being offered for the fields of assessment of industrial accidents and nuclear disasters but also for economics and sociology. These procedures are shown in Diagram 1.

In the USA, procedures arising from the economic premise of public welfare WTP (Willingness to Pay) or VLYL - inability to perform a job (Value of Life Year Lost) are used for nonlinearities cumulated in the concept of human factor. The value of statistical life (VSL) is then the ratio of average value of WTP and the change in the extent of risk after the risk minimization measures. In Europe, such procedures are used only in the insurance business. Technical sciences do not currently use this approach.

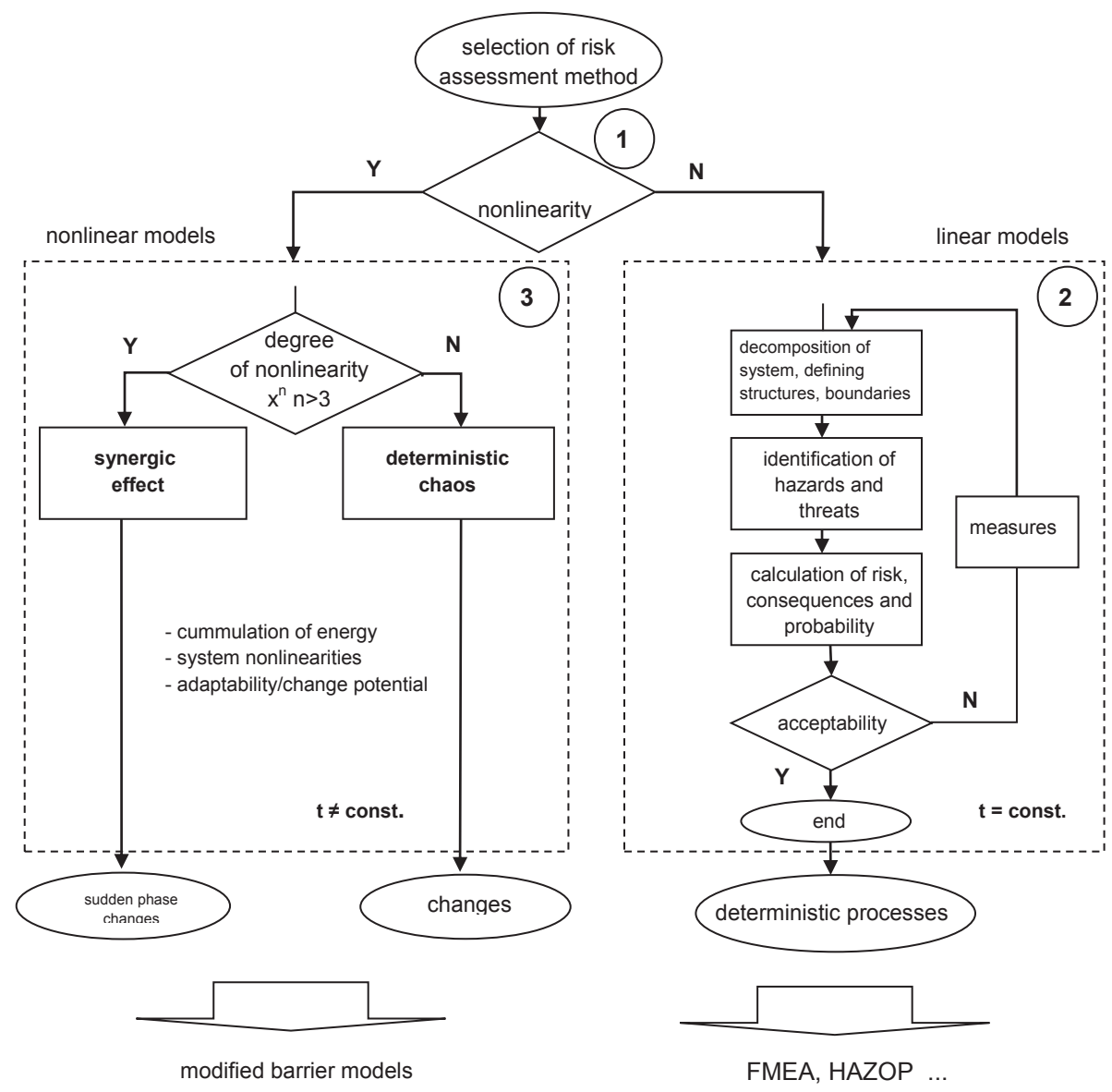

Diagram 1: Relation of linear and nonlinear risk assessment procedures [8]. 
1. Nonlinearity and system stability is determined by the relations within the system

2. Traditional risk assessment procedures, constant time and deterministic linear relations within the system

3. New causal dependence identification tools, especially hazard / risk interface. Forms of identification of nonlinear relations and the degree of nonlinearity.

Future efforts should be aimed at understanding mechanisms of nonlinearities, i.e. the left part of Diagram 1. Many findings have been sufficiently described, although not yet applied. Identification of the control parameter/s of change is frequently related to the system's sensitivity.

The formation of new qualities (sudden phase change) is possible only if:

1. there exists energy potential able to induce a change (open system in terms of the second main clause of thermodynamics),

2. the system contains nonlinearities (at least square power or higher) or higher derivatives, according to time or position coordinates,

3. several equations are necessary to describe the system (not one), multiparametric systems.

The usage of the nonlinear dynamic models is meaningful only if it is possible to prevent major losses; e.g. current procedures in the field of industrial accidents, critical infrastructure, continuity planning $[8,9]$.

The mechanism of synergic effect identification with the sequence chain is shown in Diagram 2 and its typical steps include:

1. analysis of the system parameters (system structure and relations),

2. identification of unstable components of the system and their energy potential,

3. identification of nonlinearities in the relations within the system,

4. change potential,

5. control parameter/s of change and its stability / change potential, position of the critical point of the system (parameters of sudden phase change),

6. character of a new quality,

7. external response - there always occurs a change, modification of the environment.

It is necessary to realize the particularities of the sudden phase change. Feigenbaum constant expresses the periodicity of sequenced changes and thus also possibility of taking measures. Upon com- pletion of the transformation $\mathrm{L}(\mathrm{x}) \mathrm{n}$ (nonlinear operator) it is impossible to return the system to its original condition, as its structure has changed. It may be better or worse than original. The measures, as can be seen in Diagram 2, can thus be taken efficiently only in the field marked with the red line. Causal dependence is represented by the black line and it illustrates the transformation of the system over the course of time.

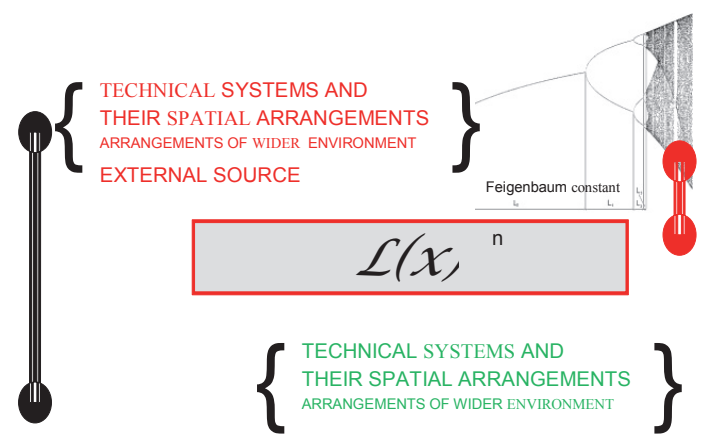

Diagram 2: Transformation of the system with a synergic effect.

An example of the abovementioned sequence of steps is the protection of important objects with the potential of undesirable attacks. Current critical infrastructure of Europe and the Slovak Republic has to be protected against such attacks $[8,10]$.

Conducting respective steps to utilize the synergic effect assumes deep knowledge of technical sciences as well as knowing the particular objects. The descriptions of simple physical laws, including nonlinearities (Table 2) are used for the quantification of consequences.

The effect of the simultaneous effect of two or more components with a phase change is generally expressed in the equation

$\frac{\partial x}{\partial t}=x^{\prime}=F\{x, r, \nabla, \Delta, t, \lambda\}$

All phenomena whose morphogenesis is expressed in differential equations (Table 2 ) and equation 8 have the potential of a phase change; they contain square or higher power $[5,11]$.

The actual actions in particular boundary conditions in the sense of point 4, diagram 2, for the field of road tunnels are shown in Table 3.

C - J model [14] is used for reaction changes in explosive burning, where some circumstances have not yet been clarified. The outcomes of such find 
Table 2: Differential equations for selected phenomena.

\begin{tabular}{|c|c|c|}
\hline Title & Equation & Note \\
\hline \multicolumn{3}{|c|}{ Technical sciences } \\
\hline Fourier's equation & $\frac{\partial t}{\partial \tau}=a \cdot \nabla^{2} \cdot t+\frac{q_{v}}{c_{p} \cdot \rho}$ & $\begin{array}{l}\text { non-stationary heat trans- } \\
\text { fer, coefficient of thermal } \\
\text { conductivity a } \neq \text { const. }\end{array}$ \\
\hline $\begin{array}{l}\text { gas dynamics of a spherical } \\
\text { flow filed }\end{array}$ & $\begin{array}{l}\frac{\partial \rho}{\partial t}+\frac{1}{r^{2}} \cdot \frac{\partial}{\partial r}\left(r^{2} \rho u\right)=0 \\
\frac{\partial \rho}{\partial t}(\rho u)+\frac{1}{r^{2}} \cdot \frac{\partial}{\partial r}\left(r^{2} \rho u^{2}\right)+\frac{\partial p}{\partial r}=0 \\
\frac{\partial \rho}{\partial t}\left[\rho\left(e+1 / 2 u^{2}\right)\right]+\frac{1}{r^{2}} \cdot \frac{\partial}{\partial r}\left[r^{2} u\left(e+1 / 2 u^{2}\right)\right]+ \\
+\frac{1}{r^{2}} \cdot \frac{\partial}{\partial r}\left(r^{2} p u\right)=0\end{array}$ & description of explosions \\
\hline \multicolumn{3}{|c|}{ Natural sciences } \\
\hline Magnetism & $\frac{\partial M}{\partial t}=a \cdot\left(T-T_{C}\right) \cdot M-b \cdot M^{3}$ & $\begin{array}{l}\text { health care, } \\
\text { military establishments }\end{array}$ \\
\hline Korteweg-de Vries equation & $\frac{\partial y}{\partial t}=a \cdot \frac{\partial^{2} y}{\partial x^{2}}+b \cdot \frac{\partial^{3} y}{\partial x^{3}}$ & tsunami \\
\hline
\end{tabular}

Table 3: Characteristic signs of sources of conflagration [12, 13, 14].

\begin{tabular}{|c|c|c|c|c|}
\hline $\begin{array}{l}\text { Source of conflagration, type of vehicle, test } \\
\text { series, test No., flow velocity vp }\end{array}$ & $\begin{array}{l}\text { Heat rate } \\
\text { [G]] }\end{array}$ & $\begin{array}{l}\text { Maximum HRR } \\
\text { [MW] }\end{array}$ & $\begin{array}{l}\text { Time to reach } \\
\text { maximum [min] }\end{array}$ & Reference \\
\hline \multicolumn{5}{|c|}{ bus } \\
\hline $\begin{array}{l}\text { Volvo school bus, } 12 \mathrm{~m} \text { long, } 40 \text { seats, EURE- } \\
\qquad \text { KA 499, vp }=0.3 \mathrm{~m} \cdot \mathrm{s}^{-1}\end{array}$ & 41 & 29 & 8 & Ingason et al \\
\hline Bus, Shimizu tunnel test, vp $=3-4 \mathrm{~m} \cdot \mathrm{s}^{-1}$ & - & 30 & 7 & Kunikane et al \\
\hline \multicolumn{5}{|c|}{ freight vehicle } \\
\hline $\begin{array}{c}10.9 \text { t wood } 82 \% \text { and plastic pallets } 18 \%, \\
\text { Runnehamar test, } v p=3 \mathrm{~m} \cdot \mathrm{s}^{-1}\end{array}$ & 240 & 203 & 18 & $\begin{array}{l}\text { Ingason and Lönner- } \\
\text { mark }\end{array}$ \\
\hline $\begin{array}{l}6.8 \mathrm{t} \text { wodden pallets } 82 \% \text { and } 18 \% \text { PUR } \\
\text { mattresses, Runnehamar test, vp }=3 \mathrm{~m} \cdot \mathrm{s}^{-1}\end{array}$ & 129 & 158 & 14 & $\begin{array}{l}\text { Ingason and Lönner- } \\
\text { mark }\end{array}$ \\
\hline $\begin{array}{c}\text { DAF 310ATi, } 2 \text { t furniture EUREKA 499, } \\
\qquad v p=3-6 \mathrm{~m} \cdot \mathrm{s}^{-1}\end{array}$ & 87 & 128 & 18 & Grant and Drysdale \\
\hline $\begin{array}{l}8.5 \text { t furniture, equipment and tires, Runne- } \\
\text { hamar test, } v p=3 \mathrm{~m} . \mathrm{s}^{-1}\end{array}$ & 152 & 125 & 10 & $\begin{array}{l}\text { Ingason and Lönner- } \\
\text { mark }\end{array}$ \\
\hline $\begin{array}{l}72 \text { wodden pallets, } 2 \text { nd Benelux test, } \\
\qquad v p=1-2 \mathrm{~m} \cdot \mathrm{s}^{-1}\end{array}$ & 19 & 25 & 12 & Lemair et al \\
\hline
\end{tabular}

ings in the consequence modelling, point 6 of Diagram 2, using MKP are prevention characteristics - both technological and organizational solutions. Figure 3 shows a vertical shift of a quarter of an interceiling plate [15] in a particular road tunnel exposed to a defined fire of $\mathrm{C}-\mathrm{H}$ curve, taking the maximums
(Table 3) into consideration. In the field of prevention and understanding the basis of the causal dependence, it is important to define the control parameter of these changes, which, in thermal conductivity, is the density of the heat flow. Knowledge of these parameters enables us to prevent the for- 
mation of synergic effect.

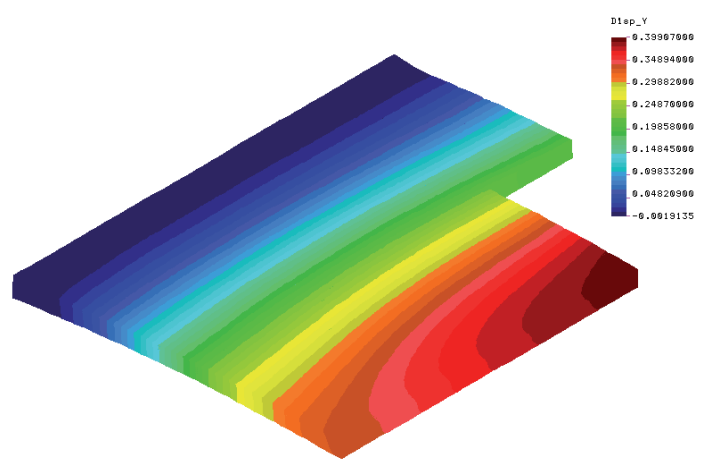

Fig. 3: Shift of a quarter of a road tunnel interceiling plate caused by fire [15].

\section{Direction of the risk theory}

Development of procedures in the field of risk assessment aims towards integral procedures, not partial ones. The direction of the theory, but also of its practical outcomes, leads towards the creation of tools usable in the near future. The currently used tools that describe causal dependence are predominantly technical, not economic. All future risk assessment methods will have to possess variability depending on the process changes and will use general system rules [6]. The methods will have to use mathematical formalism applicable for the needs of economy and safety.

The integration, the shift form partial to integral risks within the comprehensive safety, requires creation of procedures applicable across management systems. The process approach and the risk theory are unifying components in the management systems.

Safety and risks are like communicating vessels, be it in the field of safety of people, property or environment, objects situated under, on or above the ground. That is why it is necessary to set a unified terminological frame.

Newly designed procedures should focus on solving the hazard / threat interface, particular uses, which will speed up the risk assessment process. The classification of barriers in structured systems is especially important. Sensitivity analysis of complex systems is a faster indicator of potential threat than currently used identification tools.

In the sense of the systematic approach it is desirable to proceed from the human in the position of a supervisor to the human as a system component.
A system should be understood in a wider context, not only as company structure. External relations will determine industries' production in the future. Natural and social threats will cause more problems in the future. These issues will reach new dimensions in the field of crisis management and critical infrastructure. It is important to choose a special approach so that the adaptation or active protection is carried out with regard to financial and technological limitations. Influencing external threats is much more difficult than controlling internal processes within a company.

\section{Acknowledge}

This contribution is the result of the Project implementation: Research centre for efficient integration of the renewable energy sources, ITMS: 26220220064 supported by the Research \& Development Operational Programme funded by the ERDF.

\section{References}

[1] Heinrich H. W.: Industrial Accident Prevention, 3 rd ed., McGraw - Hill Book Co., New York, 1950

[2] L.v.Bertalanffy: Theoretische Biologie und Problems of Life. http://journals.isss.org/index.php/proceedings52nd/article/ viewFile/1032/322

[3] Wiener, N.: Cybernetics: or, Control and Communication in the Animal and the Machine (č. Kybernetika aneb Řízení a sdělování u organismů a strojů, SNTL, Praha 1960)

[4] Wiener, N.: The Human Use of Human Beings. Cybernetics and Society (č. Kybernetika a společnost, Nakladatelství Československé akademie věd, 1963).

[5] Prigogine, I.: From Being To Becoming, 1980, Freeman, ISBN 0-7167-1107-9.

[6] Oravec, M.: Posudzovanie rizík, SPBI Ostrava 2008, ISBN 97880-7385-043-2.

[7] Svoboda, O., Roudný, R.: Modelování souvislostí mezi hrozbami. Scientific Papers of the University of Pardubice, Series D, Faculty of Economics and Administration, 2010, vol. 15, no. 18, s. 153-163. ISSN: 1211-555X

[8] Oravec, M.: Synergický efekt - nástroj komerčného zneužitia, CNP 2011, IOO Bohdaneč 2011.

[9] Oravec,M.: Procedurálny prístup k ochrane kritickej infraštruktúry, Změna klimatu a územní bezpečnost, 100 Lázně Bohdaneč, 10/2010, ISBN 978-80-7385-090-6.

[10] Brzybohaty,M.: Terorismus jako aktualni problem globalni společnosti CNP 2011, IOO Bohdaneč 2011.

[11] Krempaský, J.: Synergetika. Základy dynamiky nelineárnych systémov, Bratislava: STU, 1994. ISBN: 8022707074.

[12] Haukur, I., Lönnermark,A.: Recent Achievements Regarding 
Measuring of Time-Heat and Time -Temperature Development in Tunnels, SNTRI, Sweden, First International Symposium, Prague 2004, str. 88-96. Safe \& Reliable Tunnels. Innovative European Achievements,

[13] Oravec,M. : Posudzovanie rizík v cestných tuneloch, EQUILIBRIA 2008, ISBN 978-80-89284-19-1.

[14] Kučera, P. et al. Požární inženýrství - Dynamika požáru. Edice SPEKTRUM, sv. 65. Ostrava: Sdružení požárního a bezpečnostního inženýrství, 2009. s. 152

[15] Rusnák O.: Medzistropná doska - rizikový prvok cestných tunelov, KDP, KBaKP, 2011 